(Кривий Ріг, 22 -25 травня 2013р.) ; в 2-х томах. - Кривий Ріг : Копіювальний центр КПІ ДВНЗ «КНУ», 2013. - Т. 2. - С. 81-84. 12. Словарь иностранных слов. - [9-е изд., испр.]. - М. : $\quad$ Рус. язык, 1982. - 608 с. $\quad$ 13. Туркот Т. И. Индивидуальнодифференцированный подход к учащимся при систематическом повторении курса физики (X-XI кл.) : дис. ... канд. пед. наук : 13.00.02 / Туркот Тетяна Іванівна. - К., 1992. - 219 с. 14. Федоровский К. Т. Индивидуальный подход к учащимся в советской школе / К. Т. Федоровский // Сов. Педагогіка. - 1937. - №3. - С. 117-132. 15. Фіногєєва Т. С. Організація самостійної роботи майбутніх інженерів-педагогів у процесі вивчення педагогічних дисциплін : дис.... канд. пед. наук : 13.00.09 / Фіногєєва Тетяна Свгенівна. - Луганськ, 2011. - 334 с. 16. Хлебникова И. В. Об индивидуальном подходе в обучении и воспитании и современность / И. В. Хлебникова, Б. Г. Ананьев // Психолого-педагогическое обеспечение учебного процесса. - М. , 1987. - С. 151-156. 17. Чередов И. М. О дифференцированном обучении на уроках / И. М. Чередов. Омск : Зап. Сиб. кн. изд-во, 1973. - 155 с. 18. Ярошенко О. Г. Порівняльний аналіз стилів навчання студентів різних спеціальностей / О. Г. Ярошенко, Т. М. Деркач// Педагогіка і психологія. - 2012. - №1. - С. 43-47. 19. Hoffmann K.-I. Möglichkeiten der didaktischen Differenzierung im Physikunterricht // Physik in der schule. - 1978. - №7-8. S. 311-317.

\title{
АНАЛІЗ РЕЗУЛЬТАТІВ УПРОВАДЖЕННЯ ДИДАКТИЧНОЇ МОДЕЛІ ФОРМУВАННЯ ПІЗНАВАЛЬНОЇ САМОСТІЙНОСТІ СТУДЕНТІВ НЕМОВНИХ СПЕЦАЛЬНОСТЕЙ У ПРОЦЕСІ ВИВЧЕННЯ ІНОЗЕМНИХ МОВ
}

Довганець В. І. Аналіз результатів упровадження дидактичної моделі формування пізнавальної самостійності студентів немовних спеціальностей у процесі вивчення іноземних мов.

У статті представлено шляхи реалізації дидактичної моделі формування пізнавальної самостійності студентів немовних спеціальностей у процесі вивчення іноземних мов. Автор аналізує результати впровадження дидактичної моделі, отримані через емпіричне дослідження об'єкта, i відтворює якісно-кількісну динаміку формування пізнавальної самостійності студентів за обраними критеріями.

Ключові слова: дидактична модель, пізнавальна самостійність, вивчення іноземних мов, шляхи реалізації, результати впровадження.

Довганец В. И. Анализ результатов внедрения дидактической модели формирования познавательной самостоятельности студентов неязыковых специальностей в процессе изучения иностранных языков.

В статье представлены пути реализации дидактической модели формирования познавательной самостоятельности студентов неязыковых специальностей в процессе изучения иностранных языков. Автор анализирует результаты внедрения дидактической модели, полученные через эмпирическое исследование объекта, и представляет качественно-количественную динамику формирования познавательной самостоятельности студентов по выбранным критериям.

Ключевые слова: дидактическая модель, познавательная самостоятельность, изучение иностранных языков, пути реализации, результаты внедрения. 
Dovganets V. I. Analysis of the implementation results of the didactic model of the cognitive independence formation of non-linguistic specialties students studying foreign languages.

The article presents the ways of realization of the didactic model of the cognitive independence formation of students of non-linguistic specialties studying foreign languages. The author analyses the implementation results of the didactic model obtained through an empirical study of the object and represents a qualitative-quantitative dynamics of students' cognitive independence formation on the selected criteria.

Key words: didactic model, cognitive independence, the study of foreign languages, ways of implementation, results of implementation.

Формування пізнавальної самостійності студента ми розглядаємо як процес становлення самостійної особистості, майбутнього фахівця, здатного навчатися протягом життя за власної ініціативи, швидко реагувати на швидкоплинні зміни в розвитку суспільно-виробничих вимог і взаємозв'язків, який в умовах ВНЗ становить собою багатогранну модель, керовану кількома сторонами (нормативні вимоги, керівництво ВНЗ, викладачі та студенти).

Управлінська функція процесом формування пізнавальної самостійності студентів значною мірою залежить від створення структурно-функціональної дидактичної моделі, у якій об'єкт розглядається як цілісна система, яку поділено на окремі елементи та підсистеми, пов'язані структурними співвідношеннями [3].

Мета статті - висвітлити шляхи формування пізнавальної самостійності студентів засобом упровадження в навчальний процес 3 вивчення іноземних мов дидактичної моделі, визначити їх ефективність через емпіричне дослідження й аналіз динаміки формування пізнавальної самостійності студентів.

Осмислення досвіду, теоретичних та практичних наробок представників педагогічних підходів (компетентнісного- І. Зимня, О. Лебедєв, С. Петрушов, О. Хуторський, С. Шишов, особистісно діяльнісного - М. Алексєєв, Б. Ананьєв, І. Бех, Н. Бібік, О. Бондаревська, Л. Виготський, П. Гальперін, О. Леонтьєв, М. Ляховицький, О. Падалка, О. Пєхота, С. Рубінштейн, М. Солдатенко, І. Якиманська, системного С. Архангельський, В. Афанасьєв, В. Беспалько, М. Данилов, В. Загвязінський, Т. Ільїна, Т. Ільясова, В. Краєвський, І. Малафіїк, В. Мізинцев, Р. Шадурі), а також аналіз практики формування пізнавальної самостійності студентів немовних спеціальностей у процесі вивчення іноземних мов дозволив розробити, обгрунтувати, упровадити в навчально-виховний процес структурно-функціональну дидактичну модель та перевірити іiї ефективність.

Дидактична модель передбачає вхідне та вихідне тестування рівня сформованості пізнавальної самостійності студентів за основними критеріями; організацію та здійснення процесу формування пізнавальної самостійності студентів через забезпечення відповідного дидактичного середовища, створеного 3 урахуванням інтегративних компонентів дидактичної системи: змістового, мотиваційно-цільового, регулятивно-стимулювального, операційно-діяльнісного, інформаційно-методичного, контрольно-оцінного. При цьому дидактичне середовище створюється через реалізацію обраних форм організації самостійної навчально-пізнавальної діяльності (самостійна робота студентів), засобів (іноземні мови, навчально-методичні комплекси, самостійна робота студентів) i методів (організації та здійснення самостійної навчальнопізнавальної діяльності, стимулювання й мотивації самостійної навчально-пізнавальної діяльності; контролю (самоконтролю, взаємоконтролю), корекції (самокорекції, взаємокорекції) самостійної навчально-пізнавальної діяльності. 
Формування мотиваційної-цільової сфери студентів відбувалося на всіх етапах організації навчального процесу вивчення іноземних мов, а саме: перед початком вивчення дисциплінарного курсу, окремо взятого модуля, теми або набуття певних знань, умінь і навичок передбачалось усвідомлення студентами необхідності виконання навчальних дій через:

- актуалізацію нормативних вимог щодо виконання навчальної програми, у більш широкому сенсі - перспективного застосування в майбутній професійній діяльності та розкриття особистісно-ціннісного сенсу цих знань, умінь і навичок для подальшого формування пізнавальної самостійності (прийом співвідношення об'єктивно й суб'єктивно значущих цілей, що сприятиме здійсненню принципового кроку вперед у цілеутворенні);

- формування у студентів настанов на успішне виконання поставленого завдання, відчуття себе «творцем обставин», що здатний подолати труднощі, які можуть зустрітися під час виконання самостійних навчально-пізнавальних дій (формування мотиву досягнень).

На етапі організації навчально-пізнавальної, зокрема самостійної діяльності студентів відбувалося усвідомлення теоретичної і практичної значущості засвоюваних знань через необхідне змістове наповнення навчальної дисципліни (професійно орієнтований зміст) і підбір навчального матеріалу як системи практичних завдань, що створюють проблемні ситуації у структурі навчальної діяльності; організація активних дій студентів щодо їх розв'язання. У цьому випадку навчальний зміст (знання і способи їх добування) перетворюється на мету навчально-пізнавальних дій студентів i усвідомлюється ними.

На етапі контролю й оцінки результативності самостійної навчально-пізнавальної діяльності задля набуття необхідних знань i умінь здійснювана дослідноекспериментальна робота передбачала зробити більший акцент на розвиток рефлексії у студентів, тому етап оцінки та самооцінки утворили інтегральну єдність.

Наприкінці семестру студент міг не лише відокремлювати відоме від невідомого, але й з'ясував, яких знань йому не вистачає для розв'язання нових завдань, він міг визначати складність навчально-пізнавального матеріалу, характеризувати помилки, висувати гіпотези щодо причин помилок, користуватися критеріями оцінки i окреслювати свої подальші перспективи.

Формування навчальних умінь здійснювалося через упровадження в навчальний процес $з$ вивчення іноземних мов дидактичних елементів (вправ, завдань, пам'яток), які ми умовно назвали «Вчимося навчатися». При цьому ми переслідували такі цілі та задачі: сприяти вдосконаленню навчальних умінь студентів, озброївши їх необхідними знаннями та методиками організації самостійної навчально-пізнавальної діяльності, а саме: 1) методикою і технікою планування й організації самостійної навчальнопізнавальної діяльності, що є одним із дієвих інструментів активізації їх самостійної роботи; 2) технікою пошуку, відбору, вилучення та раціональної організації навчальнопізнавальної інформації 3 різних інформаційних джерел; технікою самоконтролю та самооцінки власної самостійної навчально-пізнавальної діяльності.

У нашому дослідженні для пошуку оптимальної комбінації поєднання самостійності студентів і міри педагогічної допомоги викладача для організації, моніторингу та коригування самостійної навчально-пізнавальної діяльності було апробовано три варіанти навчальних ситуацій, які поетапно переходили одна в іншу 3 формуванням у студентів навичок самостійної навчально-пізнавальної діяльності: провідна роль викладача, що подає навчальний матеріал на пояснювальноінструктивному та інструктивно-практичному рівні; пояснювально-спонукальний i 
проблемний тип викладання, коли викладач визначає навчальну мету, а студент самостійно планує та організовує свою самостійну навчально-пізнавальну діяльність, застосовує ті способи і стратегії, що відповідають його індивідуальному стилю; викладач видає завдання і вказує строки його виконання, надаючи студенту можливість самому обирати способи та засоби його виконання, контролюючи тільки кінцевий результат.

Щоб уникнути розбіжності між навчальними і реальними потребами студентів у використанні іноземних мов, для формування пізнавальної самостійності ми включили до програми проблемні завдання, зорієнтовані на розв'язання певних соціальних та професійних проблем. Доцільно задля цього використовувати метод проектів.

Технологія проектного навчання передбачає практичну реалізацію продуктивного навчання i, на відміну від традиційної практики, характеризується тим, що навчальнопізнавальний процес спрямований на кінцевий результат- індивідуальний досвід продуктивної діяльності. Основою цієї технології стали ідеї Д. Дьюї [2] про організацію навчальної діяльності, що передбачає вирішення практичних задач, які виникають у повсякденному житті, й заперечення стандартизованості змісту навчання, що має на меті навчальний процес, зорієнтований на досягнення практичних цілей.

Проектна робота безпосередньо пов'язує процес набуття певних предметних знань 3 реальним їх застосуванням і використання набутих умінь у практичній, зокрема наближеній до професійної, діяльності. При цьому орієнтація на використання іноземних мов у створенні проекта як особистого навчально-пізнавального продукту робить процес засвоєння предметних знань особисто значущим i особистісно мотивованим. Метод проектів дозволяє перетворити самостійну навчально-пізнавальну діяльність студентів на дійсно продуктивний творчий процес.

Розв'язання задачі інформаційно-методичного забезпечення самостійної навчально-пізнавальної діяльності студентів викликає необхідність детального розроблення ії дидактичного забезпечення у вигляді навчально-методичних комплексів (НМК), які були б спроможні: 1) змінити організацію навчально-пізнавальної діяльності студентів зі збільшенням частини самостійної роботи студента, що забезпечить: перенесення центру тяжіння в навчанні з викладання на учіння, тобто систематичну, керовану викладачем самостійну діяльність студента, але не самоосвіту, що довільно здійснюється індивідом; зробити акцент на організації й управлінні самостійною роботою студентів; 2) перейти до оновлення технологій навчання, дидактичного i психолого-педагогічного забезпечення розв' язання задачі покращення якості освіти [1].

Експериментальні НМК із вивчення іноземних мов із акцентом на формування пізнавальної самостійності студентів охоплюють такі складники: 1) навчальні і робочі програми дисципліни «Іноземна мова», що були побудовані 3 урахуванням інтегративних зв'язків із програмами основних спеціальних предметів через вивчення логічно-структурної схеми підготовки студентів за певними напрямами; 2) банк анкет і тестових завдань для проведення ідентифікаційного, попереднього (вхідного), поточного та підсумкового контролю; 3) навчальні посібники і методичні вказівки модульного типу з дисципліни «ноземна мова»; 4) методичні вказівки для самостійної роботи студентів; 5) аудіозаписи до посібників і методичних вказівок.

Систематичне i планомірне впровадження дидактичної моделі формування пізнавальної самостійності студентів у процесі вивчення іноземних мов значно підвищило якість навчання, дозволило досягнути вищих результатів у засвоєнні студентами не тільки програмних знань, а й накопиченні досвіду самостійної творчої навчально-пізнавальної діяльності, про що свідчать результати порівняння даних, отриманих під час проведенні вхідних і вихідних контрольних зрізів, анкетувань та 
аналізу продуктів самостійної навчально-пізнавальної діяльності студентів у контрольних та експериментальних групах.

Значна частина студентів експериментальної групи володіє навчальноорганізаційними (67\%, вхідні дані - 23,7\%), навчально-інформаційними (64\%, вхідні дані - 28\%) та навчально-інтелектуальними навичками (43\%, вхідні дані - 36\%), що успішно реалізовувалися під час вилучення інформації та ії перетворення шляхом порівняння, класифікації, оцінки, узагальнення, запам'ятовування, прогнозування та визначення перехідних цілей, а також прийняття рішень на основі вибору предмета, засобів, умов та способів самостійного виконання дій.

Робота $з$ формування рефлексивних умінь, що відбувалася поетапно із залученням студентів до взаємоперевірки контрольних і самостійних робіт, колективний аналіз й оцінка результатів самостійної навчально-пізнавальної діяльності, самоаналіз студентом результатів контрольних робіт і тестових завдань із використанням шаблонів i еталонних рішень, забезпечувалося систематичним унесенням компонента рефлексії в кожне заняття, дотриманням етапності рефлексивної діяльності, поширенням рефлексії на всі компоненти навчально-пізнавальної діяльності студентів. На вхідному контролі лише $24 \%$ студентів мали рефлексію на рівні навички, і вже 59\% - на етапі вихідного контролю.

Цілеспрямований педагогічний вплив засобами інформаційно-методичного забезпечення самостійної навчально-пізнавальної діяльності студентів зумовив об’єктивну трансформацію діяльнісного рівня студентів (табл. 1). Формальне репродуктивне виконання обов'язкових навчальних завдань поступово перетворилося на пошуково-творчий пізнавальний процес. Навіть студенти із попереднім низьким рівнем навчальних умінь та іншомовної мовленнєвої комунікації із задоволенням долучалися до виконання творчих завдань, тим самим демонструючи ініціативність i зацікавленість у самостійній пізнавальній діяльності.

Таблиця 1

Рівні самостійної пізнавальної діяльності студентів (у \%)

\begin{tabular}{|c|c|c|c|c|c|}
\hline \multirow{2}{*}{ Група } & \multirow{2}{*}{$\begin{array}{c}\text { Етапи } \\
\text { тестування }\end{array}$} & $\begin{array}{c}\text { Рівень } \\
\text { ознайомлення }\end{array}$ & $\begin{array}{c}\text { Рівень } \\
\text { репродукиї }\end{array}$ & $\begin{array}{c}\text { Рівень } \\
\text { умінь }\end{array}$ & $\begin{array}{c}\text { Рівень } \\
\text { трансформаиії }\end{array}$ \\
\cline { 3 - 6 } К & $\mathrm{Bx}$ & - & 30,5 & 57,3 & 12,2 \\
\cline { 2 - 6 } & Вих & - & 30,8 & 56,4 & 12,8 \\
\hline \multirow{2}{*}{$\mathrm{E}$} & $\mathrm{Bx}$ & 5 & 46,2 & 38,8 & 10 \\
\cline { 2 - 6 } & Вих & 2 & 30,5 & 47,3 & 20,2 \\
\hline
\end{tabular}

Окрім того, у певної частини студентів експериментальної групи відбулася позитивна переорієнтація мотиваційно-цільового підгрунтя самостійної навчальнопізнавальної діяльності: зовнішні мотиви (досягнення формальної академічної успішності) трансформувалися в пізнавальні мотиви (орієнтація на засвоєння способів здобування знань, прийоми самостійного набуття знань). Студенти, що мали низький рівень професійної мотивації на вхідному тестуванні, не продемонстрували позитивних змін у мотиваційно-цільовому підгрунті своєї самостійної пізнавальної діяльності (маємо на увазі пізнавальну мотивацію), оскільки не зацікавилися професійно орієнтованим змістом навчального предмета «ноземна мова» та формально підходили до виконання програмних вимог і виконання завдань викладача, маючи зовнішню або негативну мотивацію.

Розглядаючи волю як структурний компонент ПСС з позиції ії спонукальної функції і взаємозв'язку з мотиваційною сферою особистості, ми зробили висновок, що 
однією 3 головних умов успішного формування вольових якостей $є$ зміцнення у студентів упевненості у своїх силах. Оволодівши необхідними знаннями і навчальними уміннями, які допомагають ефективній самостійній навчально-пізнавальній діяльності, студенти продемонстрували позитивні зміни в рівні розвитку вольових якостей. I навпаки, докладання вольових зусиль, зумовлених певними мотивами, допомогло студентам засвоїти необхідні знання, оволодіти уміннями й навичками здійснення самостійної навчально-пізнавальної діяльності у процесі вивчення іноземних мов.

Порівняння результатів вхідного і вихідного тестувань дозволили зробити висновок про ефективність розробленої дидактичної моделі формування пізнавальної самостійності студентів немовних спеціальностей у процесі вивчення іноземних мов, яка мала успішну практичну реалізацію завдяки дидактичним засобам, що сприяли створенню позитивної мотиваційно-цільової настанови на самостійну навчальнопізнавальну діяльність студентів; розвитку навчальних умінь студентів, які застосовувалися у здійсненні навчально-пізнавальних дій репродуктивного/ продуктивного рівня; стимулюванню регулятивної і рефлексивної сфери студентів; створенню проблемно-пошукових навчально-пізнавальних ситуацій. Результати дослідно-експериментальної роботи надають усі підстави вважати, що мету досягнуто шляхом реалізації поставлених завдань, а обрані форми, методи, прийоми і засоби сприяли ефективному здійсненню експерименту, що у свою чергу свідчить про важливість проведеного дослідження та його результатів для педагогічної науки та практики в реаліях сучасних немовних ВНЗ.

Проведене дослідження дозволило отримати позитивні результати в розв’язанні проблеми формування пізнавальної самостійності студентів немовних спеціальностей у процесі вивчення іноземних мов, проте розроблена модель не претендує на досконале і вичерпне висвітлення конкретної наукової проблеми. Подальші перспективи в дослідженні проблематики ми вбачаємо у вивченні наступності (школа - ВНЗ професійна діяльність), особливостей пізнавальної самостійності та самоосвіти в конкретних професійних умовах та умовах підвищення кваліфікації та перекваліфікації фахівців різних галузей із відривом і без відриву від виробництва.

\section{Література}

1. Алтайцев А. М. Учебно-методический комплекс как модель организации учебных материалов и средств дистанционного обучения / А. М. Алтайцев, В. В. Наумов. - Минск : БГУ, 2002. - 288 с. 2. Дьюи Дж. Демократия и образование / Дж. Дьюи [пер. с англ. Ю. И. Турчаниновой и др.]. - М. : Педагогика-Пресс, 2000. 382 с. 3. Принципи побудови моделей [Електронний ресурс]. - Режим доступу: http://wiki.kspu.kr.ua/

\section{Оксана Карабін}

\section{ПРОЕКТУВАННЯ ІНФОРМАЦЙННОГО СЕРЕДОВИЩА МАЙБУТНІХ УЧИТЕЛІВ ГУМАНІТАРНИХ ДИСЦИПЛІН}

Карабін О. Й. Проектування інформаційного середовища майбутніх учителів гуманітарних дисциплін.

У статті розглянуто поняття інформаційного середовища в процесі формування готовності майбутніх учителів гуманітарних дисциплін, виокремлено етапи створення інформаційного середовища у системі підготовки майбутніх учителів гуманітарних дисциплін, розглянуто основні теоретико-методичні положення, на яких має 